This item was submitted to Loughborough's Research Repository by the author.

Items in Figshare are protected by copyright, with all rights reserved, unless otherwise indicated.

\title{
Bridging the gap between field data and global models: current strategies in aeolian research
}

PLEASE CITE THE PUBLISHED VERSION

http://dx.doi.org/10.1002/esp.1958

PUBLISHER

(c) Wiley

VERSION

SMUR (Submitted Manuscript Under Review)

LICENCE

CC BY-NC-ND 4.0

\section{REPOSITORY RECORD}

Bullard, Joanna E.. 2019. "Bridging the Gap Between Field Data and Global Models: Current Strategies in Aeolian Research". figshare. https://hdl.handle.net/2134/8126. 
This item was submitted to Loughborough's Institutional Repository (https://dspace.lboro.ac.uk/) by the author and is made available under the following Creative Commons Licence conditions.

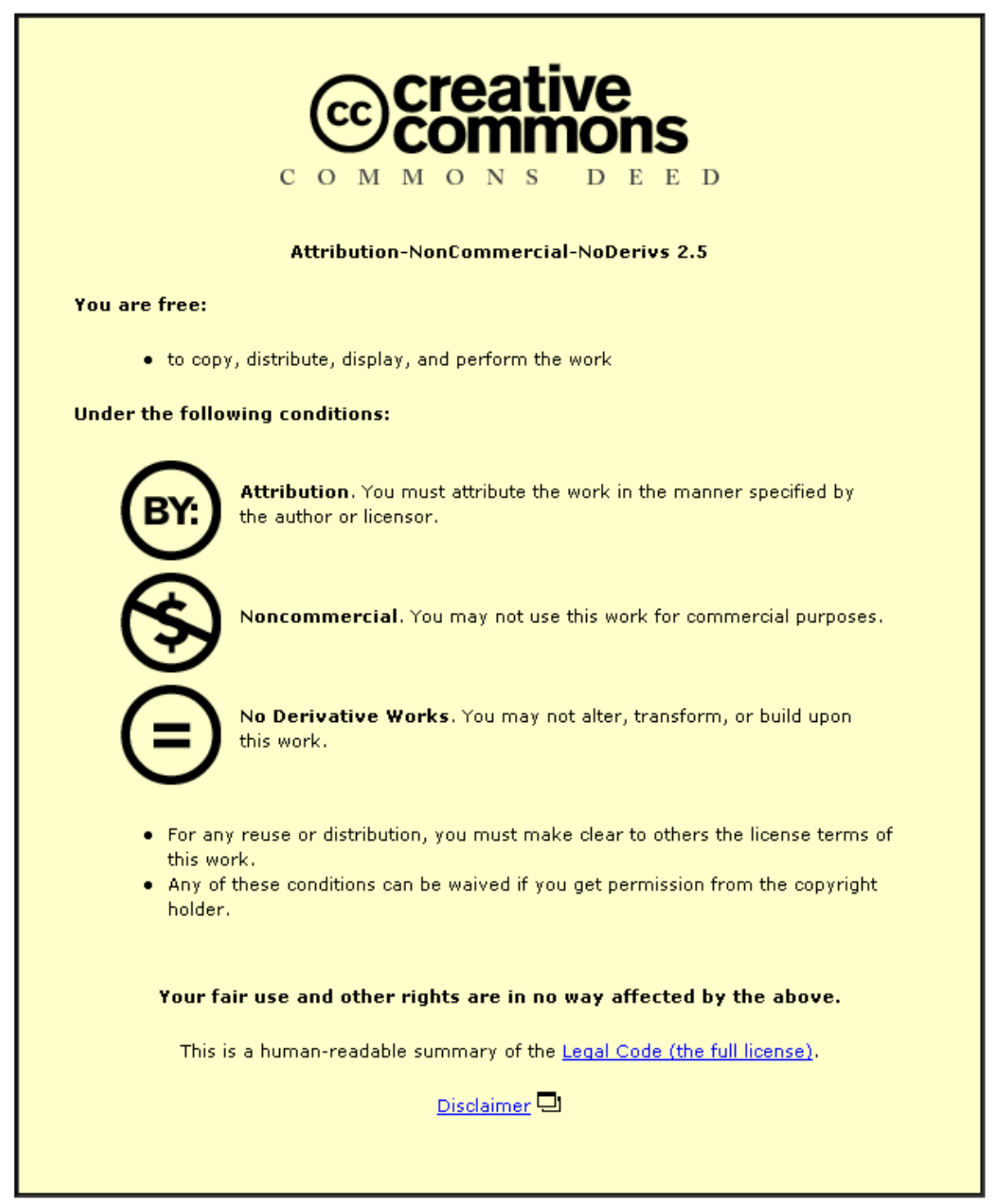

For the full text of this licence, please go to: http://creativecommons.org/licenses/by-nc-nd/2.5/ 
Bridging the gap between field data and global models: current strategies in aeolian research.

Joanna Bullard

Department of Geography, Loughborough University, Leicestershire LE11 3TU UK.

\begin{abstract}
Modern global models of earth-atmosphere-ocean processes are becoming increasingly sophisticated but still require validation against empirical data and observations. This commentary reports on international initiatives amonst aeolian researchers that seek to combine field-based data sets and geomorphological frameworks for improvising the quality of data available to constrain and validate global models. These include a second iteration of the Dust Indicators and Records from Terrestrial Marine Palaeoenvironments (DIRTMAP2) database, the Digital Atlas of Sand Seas and Dunefields of the World and a new geomorphology-based land surface map produced by the QUEST Working Group on Dust.
\end{abstract}




\section{Introduction}

Modern global models of earth-atmosphere-ocean processes used to predict future changes or past behaviour of the Earth's system are becoming increasingly sophisticated, however there is a profound need to constrain or validate such models against empirical data from in-situ field observations. For some variables included in complex models, there are integrated global networks of stations collecting at-a-point data using a defined set of criteria that can be used to test performance. For example climate and atmospheric data are available from sources such as the International Station Meteorological Climate Summary Data Set (>2600 stations) and the Aerosol Robotic Network (AERONET) data (>350 stations). For other variables global scale test data sets are incomplete, fragmented, out of date or designed for a very different purpose to that required in the model - these include soils, sediment texture, land cover and land use data sets (e.g. Tanaka 2008; GlobalSoilMap.net ${ }^{1}$ ). Although remote sensing data can provide global coverage of some surface variables there is still the need in many cases to conduct ground truth surveys and, in order to explain the occurrence of some events, considerable understanding of antecedent conditions and local relationships at a higher spatial resolution than that afforded by the sensors is required.

In many cases, although global models can give reasonable estimates of what is occurring under present-day conditions, in order to predict, or retrodict, what might happen, or have happened, under different environmental conditions it is important to understand why change occurs - for example in flood frequency, landslides, dust emissions - and hence whether the magnitude-frequency characteristics of events might be expected to change.

Field studies are a major resource that are useful for examining and explaining past and future environmental changes. They range from processbased studies recording fluxes and morphological response to stratigraphic records indicating periods of fluvial activity, sea level rise or dune emplacement. However, there are significant challenges in pulling together 
data from different individual studies including the criteria used to define variables - for example see discussions by Holden (2007) on variations in reporting of near-surface air temperature and Reid et al. (2003) comparing techniques for measuring airborne particles.

This commentary reports on two international initiatives amongst aeolian researchers that seek to provide combined field-based data sets and geomorphological frameworks for improving the quality of data available to constrain and validate global models.

\section{1) Field-based Benchmarking for Global Models}

There are currently few standards for 'benchmarking' global dust models - in other words, for testing whether the models accurately predict the processes known to have been occurring at specific locations in different periods in the past or under contemporary conditions. Globally-distributed field data collected under a defined set of comparable protocols are typically unavailable due to resource constraints (although some small, heavily used facilities such as the University of Miami aerosol work exist), however there are many locations where point data have been obtained, for example from marine, terrestrial or ice cores and active or passive samplers that can be used to build up such a network of data points.

One attempt to do this was the development of the Dust Indicators and Records from Terrestrial and MArine Palaeoenvironments ${ }^{2}$ (DIRTMAP) database, established in 1998 (Kohfled \& Harrison, 2001). It is recognised that dust has a significant influence on global climate through changes in the radiative properties of the atmosphere and/or the $\mathrm{CO}_{2}$ content of the oceans and atmosphere (Ridgwell, 2002; Jickells et al. 2005), and the amount of dust in the atmosphere also reflects changes in earth surface processes operating over glacial-interglacial cycles. The aim of DIRTMAP was to bring together point-source records of dust accumulation rates, chronological data (e.g. radiocarbon dates, luminescence dates, stratigraphic correlations), grain size and mineralogical data into a single database that could be used to evaluate 
simulations of the palaeo dust cycle from 0 to 150,000 BP. By 2002 two versions of the global dataset had been released and used to support numerous scientific publications (e.g. Harrison et al. 2001; Mahowald et al., 1999, Kohfeld and Harrison, 2001).

Although increasing numbers of papers on dust and loess are being published (Stout et al. 2009), including new field data and chronological insights, there has been limited systematic updating of the DIRTMAP database since 2002. Currently there is a new initiative to re-invigorate DIRTMAP to better serve the atmospheric, earth science and modelling communities. Global aerosol models have become more complex however they still use relatively simple parameterizations of dust (including size and entrainment threshold), and their ability to produce reasonable estimates of dust deposition is spatially and temporally variable (e.g. Mahowald et al. 2006). New data are available from terrestrial records in South America, Eurasia and the Middle East as well as marine records from the southern hemisphere which will be incorporated into DIRTMAP2 and used to better constrain the models in these areas. Greater understanding of the potential influence of dust source mineralogy, particularly the role of iron oxides in affecting aerosol radiative properties and the bioavailability of iron, and dust characteristics such as size and shape, is also driving the need for additional information in the database. No common standards for benchmarking dust-cycle models currently exist, however field scientists and modelers are working together on DIRTMAP2 to define the protocols and quality control checks for data entry to the database and to develop strategies for addressing uncertainties both in the observations and in the models.

A similar database is also being developed for aeolian research focusing on the Earth's sand dunes. The Digital Atlas of Sand Seas and Dunefields of the World $^{3}$ (SSDW) aims to develop a global digital database of chronological information indicating periods of aeolian sand deposition. Although the primary concern will be dune chronology to facilitate the reconstruction of areas of active dunefields in the past, it will also include the data on dune type necessary for interpreting dates (e.g. Muniywaka, 2005). This initiative is a 
welcome complement to the USGS A Global Study of Sand Seas (McKee, 1979) which included maps of the distribution of different dunes across most of the Earth's main desert areas derived from early Landsat imagery as well as determining characteristic wind regimes for different dune types and incorporating point-source sediment data. McKee's (1979) study has served the aeolian community very well for thirty years but, as demonstrated by Haywood et al. (2007) using the Mars Global Digital Dune Database ${ }^{4}$, the potential for extracting detailed dune morphology and dunefield extent from remote sensing data has expanded considerably. There are no plans currently to routinely include such data in the terrestrial digital atlas, however they are being compiled for some regions such as the Namib Sand Sea by the British Society for Geomorphology Sand Seas and Dunefields Fixed Term Working Group.

Both DIRTMAP and the SSDW project offer an opportunity to integrate pointsource data from numerous different studies into a common framework that can be used to test global models. In addition, they will both facilitate the identification of gaps in the database - both spatially and temporally - where additional field observations need to be made, and thus will drive forward new data collection campaigns; this has already been the case with DIRTMAP (refs). As well as improving maps of the geographic distribution of dunefields and dust deposits at different time periods, better understanding of variations in hemispheric response of the aeolian system to environmental drivers and global relationships between ice-extent and both the fine and coarse aeolian sediment system response will be facilitated.

\section{2) Geomorphology-based Surface Maps in Global Mineral Aerosol}

\section{Models}

Although any terrestrial surface with a supply of suitable-sized sediment and appropriate wind regime can be a dust source, the magnitude and frequency of dust emissions from Earth's surface is modified, directly or indirectly, by factors such as surface roughness, climate, sediment production, sediment delivery and topography, such that there exist preferential dust sources that 
can be identified at the global scale (Prospero et al. 2002; Washington et al. 2003).

The location of dust source areas has been parameterized in models of global atmospheric dust emissions in a variety of ways including the distribution of topographic depressions (Ginoux et al. 2001), presence of dry lake basins (Tegen et al. 2002), surface reflectance (Grini et al. 2005) and land surface roughness (Koven \& Fung, 2008). Where models have been able to parameterise geomorphology, vegetation cover and hydrology (e.g. Zender et al. 2003) they generally perform better than those where more simple criteria are used to define preferential dust sources but there are still considerable problems with defining surface conditions (Uno et al. 2006; Yin et al. 2007). Increasing recognition that supply-limited surfaces may be more prevalent than transport-limited surfaces in many wind erosion regions also highlights the need to incorporate interactions between the aeolian system and other geomorphological systems, notably fluvial and hydrological systems, which affect the accumulation and availability of sediment (e.g. Bullard et al. 2008; MacPherson et al. 2008).

As part of the UK Natural Environment Research Council (NERC) funded programme on Quantifying Uncertainties in the Earth System (QUEST) a number of working groups focusing on particular themes have been established. One of the goals of the QUEST Working Group on Dust ${ }^{5}$ is to develop a new geomorphology-based prefential dust source map. The group comprises both modellers and field scientists who are collaborating to try and achieve a classification scheme where the importance of earth surface processes, landforms and sediments is not overly compromised yet which is not so complex that it is unmanageable at the global scale. The map will be based on geomorphological units which can be clearly defined using globally ubiquitous data and identified as supply-limited, availability-limited or transport-capacity limited (e.g. Kocurek, 1998) with relation to the aeolian sediment system. Simple relationships identifying circumstances under which these states can change are also included as are indicators of sediment size and sorting. 
Currently, four test regions are being mapped by international teams. The impact and performance of this new preferential dust source map will be tested in a variety of global dust models including the Global Model of Aerosol Processes $^{6}$ (GLOMAP) at a variety of scales. If the geomorphology-based map can be demonstrated to provide a better indication of dust source regions in the regional runs, then it may also be possible to use it to tune emissions in the coarser global model framework. It has the potential to enable better characterisation of dust entrainment/uplift potential and to improve predictions for future and past behaviour of key source regions by integrating different geomorphological units.

\section{Concluding Remarks}

The initiatives outlined above are at different stages of development but each should enable new insights into understanding aeolian sediment systems at the global scale. The fact that the projects include researchers from around the globe and also include both those who specialise in field-based studies and those who develop and run global models will maximise their likelihood of both success and worldwide applicability. There are considerable challenges ahead, but the returns should be very high in terms of expanding the range of research questions that can be tackled and also improving predictions and retrodictions. More detail on each of the projects, progress made and also workshops and conferences related to them can be found from the group websites. 


\section{Project Websites}

${ }^{1}$ GlobalSoilMap.net

http://www.globalsoilmap.net/

${ }^{2}$ DIRTMAP (Dust Indicators and Records of Terrestrial and Marine Palaeoenvironments)2. INQUA Working Group (Project 0802). For more information see http://www.lec.lancs.ac.uk/research/LU_themes/inqua_working_group.php

${ }^{3}$ Sand seas and dunefields of the world: a digital Quaternary atlas. Funded by INQUA (Project 0704) and the Desert Research Institute (Reno, USA). For more information see http://www.dees.dri.edu/Projects/Dune Atlas/

${ }^{4}$ QUEST Working Group on Dust

http://www.bridge.bris.ac.uk/projects/dust/QWGD.htm

${ }^{5}$ GLOMAP (Global Model of Aerosol Processes)

http://researchpages.net/GLOMAP/ 


\section{References}

Bullard JE, Baddock MC, McTainsh GH, Leys JF. 2008. Sub-basin scale dust source geomorphology detected using MODIS. Geophysical Research Letters, doi:2008GL033928.

Forster, P., Ramaswamy, V., Artaxo, P., Berntsen, T., Betts, R., Fahey, D.W., Haywood, J., Lean, J., Lowe, D.C., Myhre, G., Nganga, J., Prinn, R., Raga, G., Schulz, M. \& Van Dorland, R. (2007) Changes in Atmospheric Constituents and in Radiative Forcing. In: Climate Change 2007; The Physical Science Basis. Contribution of Working Group I to the Fourth Assessment Report of the Intergovernmental Panel on Climate Change [Solomon, S., Qin, D., Manning, M., Chen, Z., Marquis, M., Averyt, K.B., Tignor, M. and Miller, H.L. (Eds)]. Cambridge University Press, Cambridge, United Kingsom and New York, NY, USA.

Ginoux P, Chin M, Tegen I, Prospero JM, Holben BN, Dubovik O, Lin S.-J. 2001. Sources and distribution of dust aerosols with the GOCART model. Journal of Geophysical Research 106 (D17), 20255-20273.

Grini A, Zender CS. 2004. Roles of saltation, sandblasting and wind speed variability on mineral dust aerosol size distribution during the Puerto Rican Dust Experiment (PRIDE). Journal of Geophysical Research 109: D07202, doi: 10.1029/2003JD004233.

Harrison SP, Kohfeld KE, Roelandt C, Claquin T. 2001. The role of dust in climate changes today, at the last glacial maximum and in the future. Earth Science Review 54: 43-80.

Hayward RK, Mullins KF, Fenton LK, Hare TM, Titus TN, Bourke MC, Colaprete A, Christensen PR. 2007. Mars global digital dune database and initial science results. Journal of Geophysical Research 112: E11007, doi:10.1029/2007JE002943

Holden J. 2007. A plea for more careful presentation of near-surface air temperature data in geomorphology. Earth Surface Processes and Landforms 32: 1433-1436. 
Jickells TD. and 18 others 2005. Global iron connections between desert dust, ocean biogeochemistry and climate. Science 308: 67-71

Kocurek G. 1998. Aeolian system response to external forcing factors - a sequence stratigraphic view of the Saharan region. In Alsharhan AS, Glennie KW, Whittle GL, Kendall CGSt.C. (Eds) Quaternary Deserts and Climatic Change. Rotterdam, Balkema, 327-349.

Kohfeld KE, Harrison SP. 2000. How well can we simulate past climates? Evalauting the models using global palaeoenvironmental datasets. Quaternary Science Reviews 19: 321-346.

Kohfeld KE, Harrison SP. 2001. DIRTMAP: the geological record of dust. Earth Sciences Reviews 54: 81-114.

Koven CD, Fung I. 2008. Identifying global dust source areas using highresolution land surface form. Journal of Geophysical Research 113: D22204, doi:10.1029/2008JD010195.

Macpherson T, Nickling WG, Gillies JA, Etymezian V. 2008. Dust emissions from undisturbed and disturbed supply-limited desert surfaces. Journal of Geophysical Research 113 F02S04. Doi:10.1029/2007/JF000800.

Mahowald N, Kohfeld KE, Hansson M, Balkanski Y, Harrison SP, Prentice IC, Schulz M, Rodhe H. 1999. Dust sources and deposition in the last glacial maximum and current climate: a comparison of model results with paleodata from ice cores and marine sediments. Journal of Geophysical Research - Atmospheres 104(D13): 15895-15916.

Mahowald NM, Muhs DR, Levis S, Rasch PJ, Yoshioka M, Zender CS, Luo C. 2006. Change in atmospheric mineral aerosols in response to climate: Last glacial period, preindustrial, modern and doubled carbon dioxide climates. Journal of Geophysical Research 111: D10202, doi:10.1029/2005JD006653.

McKee ED. 1979. A Study of Global Sand Seas. USGS Professional Paper 1052. 
Munyikwa K. 2005. The role of dune morphogenetic history in the interpretation of linear dune luminescence chronologies: a review of linear dune dynamics. Progress in Physical Geography 29: 317-336.

Prospero JM, Ginoux P, Torres O, Nicholson SE, Gill TE. 2002.

Environmental characterization of global sources of atmospheric soil dust identified with the Nimbus 7 Total Ozone Mapping Spectrometer (TOMS) absorbing aerosol product. Reviews of Geophysics 40, 1, art.no.1002.

Reid JS, Jonsson HH, Maring HB, Smirnov A, Savoie DL, Cliff SS, Reid EA, Livingston JM, Meier MM, Dubovik O, Tsay S.-C. 2003. Comparison of size and morphological measurements of coarse mode dust particles from Africa. Journal of Geophysical Research 108: D19, 8593, doi:10.1029/2002/JD002485.

Ridgwell AJ. 2002. Dust in the Earth system: the biogeochemical linking of land, air and sea. Philosophical Transactions of the Royal Society of London A360: 1801, 2905-2924.

Stout JE, Warren A, Gill TE. 2009. Publication trends in aeolian research: an analysis of the Bibliography of Aeolian Research. Geomorphology, 105: 6-17.

Tanaka TY. 2008. Dust emission and deposition in global models. Paper presented at $3^{\text {rd }}$ International Workshop on Mineral Dust, September 15-17 2008, Leipzig, Germany.

Tegen I, Harrison SP, Kohfeld K, Prentice IC, Coe M, Heimann M. 2002. Impact of vegetation and preferential source areas on global dust aerosol: results from a model study. Journal of Geophysical Research, 107: 4576, doi:10.1029/2001JD000963.

Thomas DSG, Wiggs GFS 2008. Aeolian system responses to global change: challenges of scale, process and temporal integration. Earth Surface Processes and Landforms, 33: 1396-1418.

Uno I, Wang Z, Chiba M, Chun YS, Gong SL, Hara Y, Jung E, Lee S.-S, Liu M, Mikami M, Music S, Mickovic S, Satake S, Shao Y, Song Z, 
Sugimoto N, Tanaka T, Westphal DL. 2006. Dust model intercomparison (DMIP) study over Asia: overview. Journal of Geophysical Research 111: D12213, doi:10.1029/2005JD006575.

Washington R, Todd M, Middleton NJ, Goudie AS 2003. Dust-storm source areas determined by the Total Ozone Monitoring Spectrometer and surface observations. Annals of the Association of American Geographers 93: 297-313.

Yin D, Nickovic S, Sprigg WA 2007. The impact of using different land cover data on wind-blown desert dust modelling results in the southwestern United States Atmospheric Environment 41: 2214-2224.

Zender CS, Newman DJ, Torres O. 2003. Spatial heteorogeneity in aeolian erodibility: uniform, topographic, geomorphic and hydrologic hypotheses Journal of Geophysical Research 108(D17): 4543, doi:10.1029/2002JD003,039. 